\title{
Geochemical and Modal Data for Igneous Rocks Associated with Epithermal Mineral Deposits
}

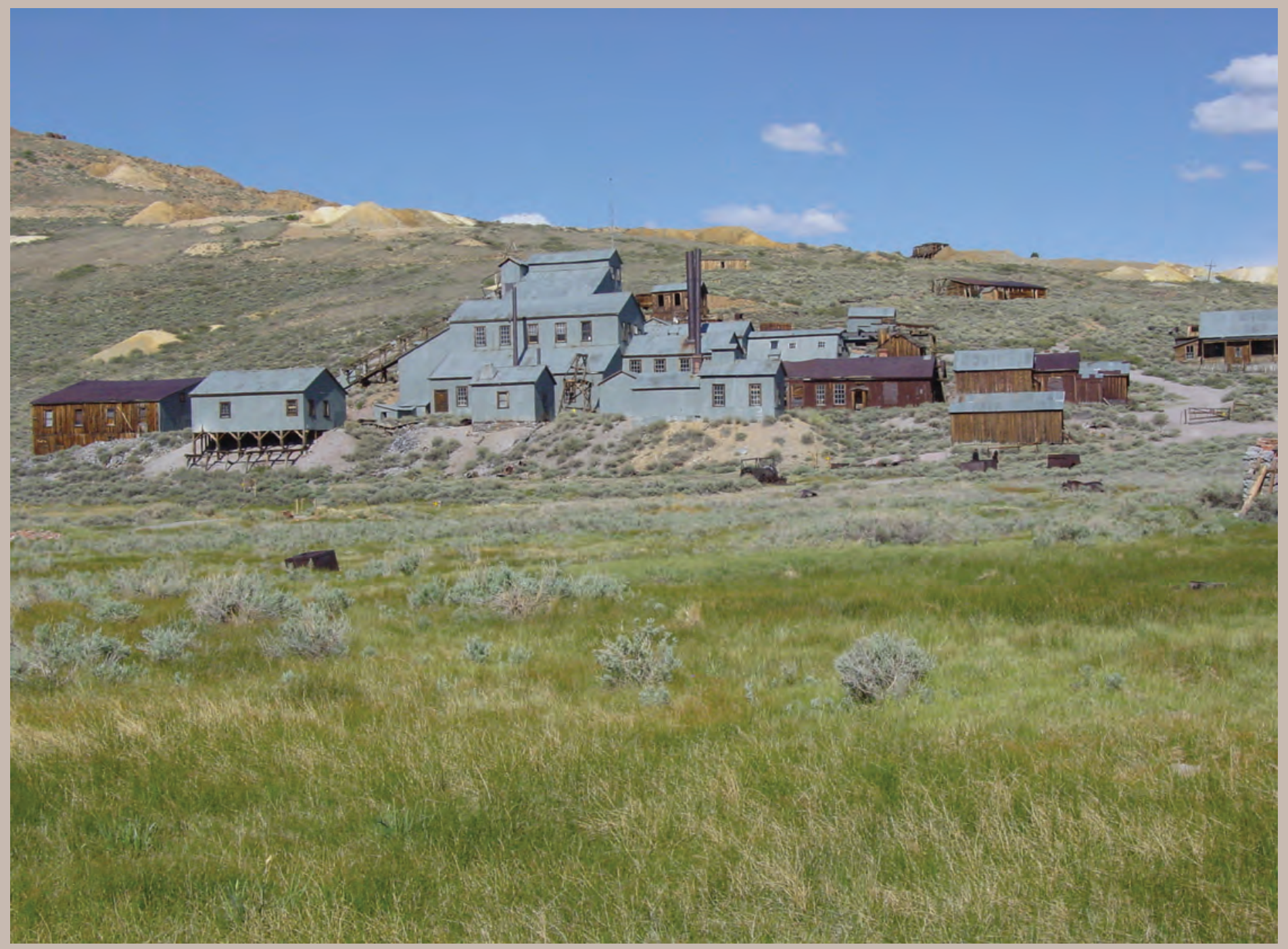

Data Series 875

U.S. Department of the Interior

U.S. Geological Survey 
COVER. The Standard Mill and the south slope of Bodie Bluff in the Bodie district, eastern California. Photo taken by Edward A. du Bray, U.S. Geological Survey, 2012. 


\section{Geochemical and Modal Data for Igneous Rocks Associated with Epithermal Mineral Deposits}

By Edward A. du Bray

Data Series 875 


\title{
U.S. Department of the Interior SALLY JEWELL, Secretary
}

\section{U.S. Geological Survey Suzette M. Kimball, Acting Director}

\author{
U.S. Geological Survey, Reston, Virginia: 2014
}

For more information on the USGS - the Federal source for science about the Earth, its natural and living resources, natural hazards, and the environment, visit http://www.usgs.gov or call 1-888-ASK-USGS.

For an overview of USGS information products, including maps, imagery, and publications, visit http://www.usgs.gov/pubprod

To order this and other USGS information products, visit http://store.usgs.gov

Any use of trade, firm, or product names is for descriptive purposes only and does not imply endorsement by the U.S. Government.

Although this information product, for the most part, is in the public domain, it also may contain copyrighted materials as noted in the text. Permission to reproduce copyrighted items must be secured from the copyright owner.

Suggested citation:

du Bray, E.A., 2014, Geochemical and modal data for igneous rocks associated with epithermal mineral deposits: U.S. Geological Survey Data Series 875, 13 p., http://dx.doi.org/10.3133/ds875.

ISSN 2327-638X (online) 


\section{Contents}

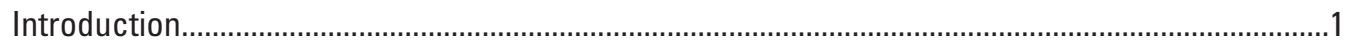

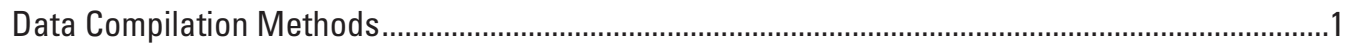

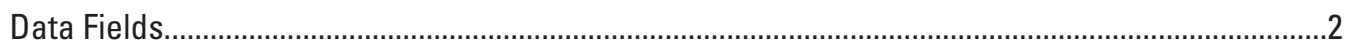

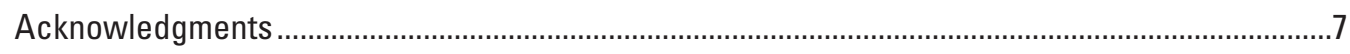

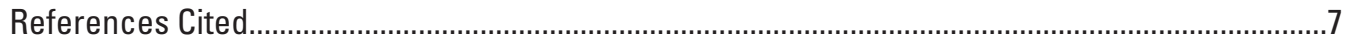

Appendix 1. Geochemical and Modal Data for Epithermal Deposits ..........................................13

\section{Table}

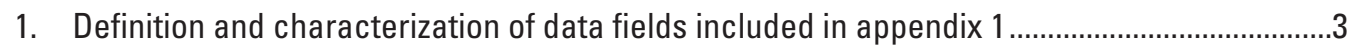





\title{
Geochemical and Modal Data for Igneous Rocks Associated with Epithermal Mineral Deposits
}

\author{
By Edward A. du Bray
}

\section{Introduction}

The purposes of this report are to (1) present available geochemical and modal data for igneous rocks associated with epithermal mineral deposits and (2) to make those data widely and readily available for subsequent, more in-depth consideration and interpretation. Epithermal precious and base-metal deposits are commonly associated with subduction-related calc-alkaline to alkaline arc magmatism as well as back-arc continental rift magmatism (Simmons and others, 2005). These deposits form in association with compositionally diverse extrusive and intrusive igneous rocks. Temperature and depth regimes prevailing during deposit formation are highly variable. The deposits form from hydrothermal fluids that range from acidic to near-neutral $\mathrm{pH}$, and they occur in a variety of structural settings. The disparate temperature, pressure, fluid chemistry, and structural controls have resulted in deposits with wide ranging characteristics. Economic geologists have employed these characteristics to develop classification schemes for epithermal deposits and to constrain the important genetic processes responsible for their formation.

Most epithermal deposit classification schemes recognize two principal classes of epithermal deposits, as defined by their gangue mineralogy (Simmons and others, 2005). One class typically includes quartz, adularia, calcite, and illite (abbreviated herein as quartz-adularia deposits); the associated deposits are generally synonymous with the low- to intermediate-sulfidation epithermal deposits of Einaudi and others (2003). The other assemblage typically includes quartz, alunite, pyrophyllite, dickite, and kaolinite (abbreviated herein as quartz-alunite deposits); these deposits are generally synonymous with high-sulfidation epithermal deposits. A third, somewhat distinct, class of epithermal gold-silver \pm tellurium deposits, with relatively few members but important because of their large size, occur in alkaline volcanic rocks. The compilation described here was undertaken in support of updating mineral deposit models for quartz-adularia and quartz-alunite epithermal deposits; a parallel effort (K.D. Kelley, oral commun., 2014) will produce a new model for alkaline intrusionrelated epithermal gold deposits. Accordingly, data compiled as part of the effort described here are restricted to the igneous rocks associated with the quartz-adularia and quartz-alunite types of epithermal deposits.

\section{Data Compilation Methods}

Simmons and others (2005) defined a representative subset of epithermal deposits whose characteristics exemplify those of this broad class of deposits. The quartz-adularia and quartz-alunite members of the representative deposit subset of Simmons and others (2005) (but excluding alkaline intrusionrelated epithermal gold deposits) served as the basis for data compilation described here. In particular, primary reference citations itemized for each of the representative deposits were examined and then pertinent geochemical and modal data were compiled. The search for additional data was further expanded by examining potentially pertinent references cited in each of the primary publications.

Demonstrating that a particular epithermal deposit is genetically related to an individual igneous rock unit is seldom possible. Nearly any rock type can host these deposits, but host relations do not demonstrate genetic relations. Therefore, criteria to establish plausible relations between deposit formation and associated igneous rocks must be established. Igneous rocks that are temporally and spatially related to a particular epithermal deposit may be associated with the genesis of that deposit. For this report, igneous rocks whose ages are within several million years, either older or younger, of the deposit age and located within $\leq 10$ kilometers of the deposit are considered to have a possible genetic relation to the particular deposit. Consequently, igneous rocks having these spatial and temporal associations with an epithermal deposit are accepted as those whose characteristics best exemplify the igneous rocks associated with deposit genesis; the geochemical and modal data for these rocks are included in the compilation described here.

Original data source materials (subsequently referred to as sources), including published reports and theses, were used to add information to the database. Altered samples were identified using standard geochemical criteria. Specifically, for the purposes of this compilation, altered samples are those with any of the following characteristics: $\mathrm{SiO}_{2}$ abundances greater than 79 weight percent, $\mathrm{Na}_{2} \mathrm{O}$ abundances less than 1.0 weight percent, $\mathrm{Na}_{2} \mathrm{O} / \mathrm{K}_{2} \mathrm{O}>7, \mathrm{CO}_{2}$ concentrations greater than 1.5 weight percent, sulfur abundances greater than 0.5 weight percent, or loss on ignition (LOI) values greater than 4 weight percent; samples with any of these 
characteristics probably do not preserve primary igneous rock compositions, and the associated data were excluded from the compilation. These metrics are somewhat beyond abundances typical of igneous rocks, but because most rocks within the halo of epithermal deposits have at least some hydrothermal alteration, some weakly altered rocks may have been retained in the compilation.

Compiling analytical methods and associated estimates of precision and accuracy associated with the reported data was beyond the scope of this effort. Analytical protocols, precision, and accuracy were highly variable among sources. Fortunately, most sources document these parameters so that associated questions can be resolved by referring to the appropriate data source.

Reference lists contained in the data sources were examined and used to identify additional potential data sources. In this way, data for 1,497 samples from 60 sources were identified and incorporated in the database. This process has probably resulted in identification and incorporation of the majority of compositional data available for the representative epithermal deposits. For a sample to be included in the database, at least a sample identification and a major oxide analysis were required. Data were compiled using Microsoft Excel and can be accessed using software compatible with .xlsx files. The database release file is titled EpiMdlDB.xlsx.

Starting with original information extracted from the sources, the geochemical data were processed to enhance their usability. Specifically, all censored values were replaced by blank cells and because different sources report iron concentrations determined by different analytical protocols, the mode of iron-abundance data presentation required standardization. For some samples, abundances of both ferric and ferrous iron were reported in the source. In contrast, other sources report only total iron abundances as either $\mathrm{Fe}_{2} \mathrm{O}_{3}$ or $\mathrm{FeO}$. In most samples, reported ferrous- and ferric-iron abundances are unlikely to represent magmatic values because of variable oxidation during late- to post-magmatic processes. Therefore, to facilitate meaningful comparison of oxide abundances, all iron abundances were converted to ferrous iron (reported in the FeO_pct column), and each major oxide analysis was recalculated to 100 percent on a volatile-free basis. Modal data, the relative proportions of phenocrysts in particular rock samples, were determined for some igneous rock samples for which geochemical data were compiled. All modal data contained in the source publications are included in the data compilation (appendix 1). The worksheet tab titled GeochemData contains the data described above.

Disproportionately large numbers of geochemical analyses are available for igneous rocks associated with several of the representative epithermal deposits. Inclusion of all of these analyses in the interpretation of the geochemical systematics of igneous rocks associated with epithermal deposits would bias the interpreted dataset. Accordingly, an abbreviated, derivative version of the principal database was created by reducing the number of analyses of samples of igneous rocks associated with the Bodie and Aurora, Comstock, Martha Hill-Favona, and Banska deposits. The randomly selected subset of analyses for igneous rocks associated with these deposits constitutes an appropriately abridged, derivative version of the main data compilation; this is the dataset most suitable for synthesis and interpretation. The worksheet tab titled GeochemDataSubset contains the data described above.

\section{Data Fields}

Geochemical and petrographic data are presented in columns or sets of related columns (appendix 1) in a Microsoft Excel 2010 workbook (.xlsx format). The contents of appendix 1 include geochemical and modal data for analyzed samples (data fields defined in table 1). Geochemical data in some worksheet cells may appear to be more precise than displayed values, but the implied precision is a misleading artifact of computational processes (for instance, recalculation to 100-percent volatile free) used to create data-cell contents. Blank cells in the worksheet appendix indicate null values or that no data are available. In appendix 1, some blank cells reflect abundances that were reported as "less than the detection limit"; these values were replaced by blank cells to enable statistical analysis of the uncensored data. 
Table 1. Definition and characterization of data fields included in appendix 1.

\begin{tabular}{|c|c|}
\hline FIELD_NAME & FIELD_DESCRIPTION \\
\hline Deposit_name & Name of deposit as defined by Simmons and others (2005) \\
\hline Country & Name of country in which deposit is located \\
\hline Deposit_type & $\begin{array}{l}\text { The primary gangue-mineral assemblage, whether quartz-adularia or quartz-alunite, and defines which of the } \\
\text { epithermal model subtypes each deposit represents }\end{array}$ \\
\hline Field_Number & Field-assigned sample identifier as defined in the publication identified in the Data_source column \\
\hline Lithology & $\begin{array}{l}\text { Sample composition according to the classification scheme of Le Maitre (2002) for volcanic rocks or Streckeisen } \\
\text { (1976) for intrusive rocks }\end{array}$ \\
\hline Ign_Form & $\begin{array}{l}\text { Form (lava flow, lava dome, dike, sill, plug, pluton, tuff, and so forth) of the igneous rock represented by each } \\
\text { sample, where known }\end{array}$ \\
\hline $\mathrm{SiO} 2 \_$pct & $\begin{array}{l}\text { Silicon, as silicon dioxide, in weight percent; based on major oxide data recalculated to } 100 \text { percent on a volatile- } \\
\text { free basis }\end{array}$ \\
\hline TiO2_pct & $\begin{array}{l}\text { Titanium, as titanium dioxide, in weight percent; based on major oxide data recalculated to } 100 \text { percent on a } \\
\text { volatile-free basis }\end{array}$ \\
\hline $\mathrm{A} 12 \mathrm{O} 3 \_\mathrm{pct}$ & $\begin{array}{l}\text { Aluminum, as aluminum trioxide, in weight percent; based on major oxide data recalculated to } 100 \text { percent on a } \\
\text { volatile-free basis }\end{array}$ \\
\hline $\mathrm{FeO} \_$pct & $\begin{array}{l}\text { Total iron, as ferrous oxide, in weight percent; based on major oxide data recalculated to } 100 \text { percent on a } \\
\text { volatile-free basis }\end{array}$ \\
\hline MnO_pct & $\begin{array}{l}\text { Manganese, as manganese oxide, in weight percent; based on major oxide data recalculated to } 100 \text { percent on a } \\
\text { volatile-free basis }\end{array}$ \\
\hline $\mathrm{MgO} \_$pct & $\begin{array}{l}\text { Magnesium, as magnesium oxide, in weight percent; based on major oxide data recalculated to } 100 \text { percent on a } \\
\text { volatile-free basis }\end{array}$ \\
\hline $\mathrm{CaO} \_$pet & $\begin{array}{l}\text { Calcium, as calcium oxide, in weight percent; based on major oxide data recalculated to } 100 \text { percent on a volatile- } \\
\text { free basis }\end{array}$ \\
\hline $\mathrm{Na} 2 \mathrm{O} \_$pct & $\begin{array}{l}\text { Sodium, as sodium oxide, in weight percent; based on major oxide data recalculated to } 100 \text { percent on a volatile- } \\
\text { free basis }\end{array}$ \\
\hline $\mathrm{K} 2 \mathrm{O} \_$pct & $\begin{array}{l}\text { Potassium, as potassium oxide, in weight percent; based on major oxide data recalculated to } 100 \text { percent on a } \\
\text { volatile-free basis }\end{array}$ \\
\hline $\mathrm{P} 2 \mathrm{O} 5 \_$pct & $\begin{array}{l}\text { Phosphorus, as phosphorus pentoxide, in weight percent; based on major oxide data recalculated to } 100 \text { percent } \\
\text { on a volatile-free basis }\end{array}$ \\
\hline LOI_pct & Volatile content lost on ignition, in weight percent \\
\hline $\mathrm{H} 2 \mathrm{Ob}(+) \_$pct & Structurally bound or essential water, in weight percent \\
\hline H2Om(-)_pct & Nonessential moisture, in weight percent \\
\hline $\mathrm{CO} 2 \_$pet & Carbon dioxide, in weight percent \\
\hline Cl_pct & Chlorine, in weight percent \\
\hline F_pct & Fluorine, in weight percent \\
\hline S_pct & Sulfur, in weight percent \\
\hline Total_I_pct & Initial, pre-recalculation sum of oxide abundances, in weight percent \\
\hline Volatile_pct & $\begin{array}{l}\text { Total volatile content, in weight percent; calculated as the sum of moisture, bound water, carbon dioxide, chorine, } \\
\text { fluorine, and sulfur or as the content lost on ignition }\end{array}$ \\
\hline Ba_ppm & Barium, in parts per million \\
\hline Be_ppm & Beryllium, in parts per million \\
\hline Cs_ppm & Cesium, in parts per million \\
\hline $\mathrm{Rb} \_\mathrm{ppm}$ & Rubidium, in parts per million \\
\hline Sr_ppm & Strontium, in parts per million \\
\hline Y_ppm & Yttrium, in parts per million \\
\hline $\mathrm{Zr} \_$ppm & Zirconium, in parts per million \\
\hline Hf_ppm & Hafnium, in parts per million \\
\hline
\end{tabular}


Table 1. Definition and characterization of data fields included in appendix 1.-Continued

\section{FIELD_NAME}

\begin{tabular}{|c|c|}
\hline $\mathrm{Nb} \_p p m$ & Niobium, in parts per million \\
\hline Th_ppm & Thorium, in parts per million \\
\hline U_ppm & Uranium, in parts per million \\
\hline Ga_ppm & Gallium, in parts per million \\
\hline La_ppm & Lanthanum, in parts per million \\
\hline Ce_ppm & Cerium, in parts per million \\
\hline Pr_ppm & Praseodymium, in parts per million \\
\hline Nd_ppm & Neodymium, in parts per million \\
\hline Sm_ppm & Samarium, in parts per million \\
\hline Eu_ppm & Europium, in parts per million \\
\hline Gd_ppm & Gadolinium, in parts per million \\
\hline Tb_ppm & Terbium, in parts per million \\
\hline Dy_ppm & Dysprosium, in parts per million \\
\hline Ho_ppm & Holmium, in parts per million \\
\hline Er_ppm & Erbium, in parts per million \\
\hline Tm_ppm & Thulium, in parts per million \\
\hline Yb_ppm & Ytterbium, in parts per million \\
\hline Lu_ppm & Lutetium, in parts per million \\
\hline Ag_ppm & Silver, in parts per million \\
\hline $\mathrm{Au} \_$ppm & Gold, in parts per million \\
\hline Co_ppm & Cobalt, in parts per million \\
\hline Cr_ppm & Chromium, in parts per million \\
\hline Ni_ppm & Nickel, in parts per million \\
\hline Sc_ppm & Scandium, in parts per million \\
\hline V_ppm & Vanadium, in parts per million \\
\hline $\mathrm{Cu} \_p p m$ & Copper, in parts per million \\
\hline Mo_ppm & Molybdenum, in parts per million \\
\hline $\mathrm{Pb} \_\mathrm{ppm}$ & Lead, in parts per million \\
\hline Zn_ppm & Zinc, in parts per million \\
\hline Sn_ppm & Tin, in parts per million \\
\hline W_ppm & Tungsten, in parts per million \\
\hline Ta_ppm & Tantalum, in parts per million \\
\hline As_ppm & Arsenic, in parts per million \\
\hline $\mathrm{Sb} \_\mathrm{ppm}$ & Antimony, in parts per million \\
\hline B_ppm & Boron, in parts per million \\
\hline
\end{tabular}


Table 1. Definition and characterization of data fields included in appendix 1.-Continued

\section{FIELD_NAME}

Data source

\section{FIELD_DESCRIPTION}

Source of data; for a few samples, data were culled from two or more sources; for example, major oxide data may have been compiled from one source and trace element data from another. Data Src entries are indexed to numbered entries below:

1. du Bray and others (2013)

2. du Bray, E.A., U.S. Geological Survey, unpublished data, 2014

3. du Bray and others (2008)

4. Vikre (1985)

5. John and others (2003)

6. John, D.A., U.S. Geological Survey, unpublished data, 2014

7. Losada-Calderon and others (1994)

8. Nemeth (1976)

9. Redwood (1987)

10. du Bray and others (1995)

11. Kamenov and others (2007)

12. Dubé and others (1998)

13. Warren and others (2004)

14. Kay and others (1987)

15. So and others (1998)

16. Blesa (2004)

17. Thompson and others (1994)

18. Fytikas and others (1986)

19. Simmons and Browne (1990)

20. Van Leeuwen and others (1990)

21. Izawa and others (1990)

22. Izawa and Cunningham (1989)

23. Loucks and others (1988)

24. Izawa and Zeng (2001)

25. Booden and others (2012)

26. Booden and others (2010)

27. Staude (1995)

28. Noble and McKee (1999)

29. Hedenquist and others (1998)

30. Roşu and others (2004)

31. Cunningham and others (1989)

32. Arribas and others (1995)

33. Di Battistini and others (1987)

34. Konečný and others (1995)

35. Steven and Ratté (1960)

36. Weihed and others (1996)

37. Altunkaynak and Yilmaz (1998)

38. Ratté and Steven (1967)

39. Lipman (1975)

40. Hwang and Meyer (1983)

41. Turner (1997)

42. Chen and Huh (1982)

43. Boden (1994)

44. Nash and others (1990)

45. Nash and others (1995)

46. Henry and others (2003)

47. Wells (1937)

48. Maksaev and others (1984)

49. Leavitt and Arehart (2005)

50. Innocenti and others (1981)

51. Ransome and others (1910)

52. Sherlock (1993)

53. Thorson (1971)

54. Jiang and others (2013)

55. Hollings and others (2011)

56. Chiaradia and others (2004)

57. Chiaradia and others (2009)

58. Longo and others (2000)

59. Montgomery (2012)

60. Bissig and others (2003) 
Table 1. Definition and characterization of data fields included in appendix 1.-Continued

\section{FIELD_NAME}

FIELD_DESCRIPTION

Strat Name

Abd_Pl_phenos

Abd_AlkFld_phenos

Abd_Qtz_phenos

Abd_Hbl_phenos

Abd_Opx_phenos

Abd_Cpx_phenos

Abd_Ol_phenos

Abd_Bt_phenos

Abd_Opq

Abd_Alt
Available formal or informal stratigraphic nomenclature for igneous rock represented by sample

Modal abundance of plagioclase phenocrysts relative to the whole rock, in volume percent; TR, trace $(<0.5$ volume percent) amounts

Modal abundance of alkali feldspar phenocrysts relative to the whole rock, in volume percent; TR, trace $(<0.5$ volume percent) amounts

Modal abundance of quartz phenocrysts relative to the whole rock, in volume percent; TR, trace $(<0.5$ volume percent) amounts

Modal abundance of hornblende phenocrysts relative to the whole rock, in volume percent; TR, trace $(<0.5$ volume percent)

Modal abundance of orthopyroxene phenocrysts relative to the whole rock, in volume percent; TR, trace $(<0.5$ volume percent) amounts

Modal abundance of clinopyroxene phenocrysts relative to the whole rock, in volume percent; TR, trace $(<0.5$ volume percent) amounts

Modal abundance of olivine phenocrysts relative to the whole rock, in volume percent; TR, trace $(<0.5$ volume percent) amounts

Modal abundance of biotite phenocrysts relative to the whole rock, in volume percent; TR, trace $(<0.5$ volume percent) amounts

Modal abundance of opaque iron-titanium oxide minerals relative to the whole rock, in volume percent; TR, trace $(<0.5$ volume percent)

Modal total alteration mineral content relative to the whole rock, in volume percent; TR, trace $(<0.5$ volume percent) amounts 


\section{Acknowledgments}

Data compilation undertaken for this study was conducted as part of the New Mineral Deposit Models for Gold, Phosphate Rare Earth Elements, and Placer Rare Earth Element-Titanium Resources Project funded by the U.S. Geological Survey Mineral Resources Program. The staff of the U.S. Geological Survey Denver Library used the interlibrary loan process to obtain many of the geologic reports on which this compilation is based. Constructive reviews by Jeffrey L. Mauk and Matthew Granitto are much appreciated and helped clarify data presentation.

\section{References Cited}

Altunkaynak, Ș., and Yilmaz, Y., 1998, The Mount Kozak magmatic complex, western Anatolia: Journal of Volcanology and Geothermal Research, v. 85, p. 211-231.

Arribas, Antonio., Jr., Cunningham, C.G., McKee, E.H., Rye, R.O., Rytuba, J.J., Tosdal, R.T., Wasserman, M.D., and Aoki, Masahiro, 1995, Compilation of sample preparation and analytical methods and results of chemical, isotopic, and fluid inclusion analyses, Rodalquilar gold-alunite deposit, Spain: U.S. Geological Survey Open-File Report 95-221, $33 \mathrm{p}$.

Bissig, T., Clark, A.H., Lee, J.W., and von Quadt, A., 2003, Petrogenetic and metallogenetic responses to Miocene slab flattening; new constraints from the El Indio-Pascua Au-Ag$\mathrm{Cu}$ belt, Chile/Argentina: Mineralium Deposita, v. 38, p. 844-862.

Blesa, A., 2004, Geology and mineralization of the Esquel area, Patagonia, Argentina: Golden, Colorado School of Mines, M.S. thesis, 390 p.

Boden, D.R., 1994, Mid-Tertiary magmatism of the Toquima caldera complex and vicinity, Nevada-Development of explosive high-K, calc-alkaline magmas in the central Great Basin, USA: Contributions to Mineralogy and Petrology, v. 116, p. 247-276.

Booden, M.A., Smith, I.M., Mauk, J.L., and Black, P.M., 2010, Evolving volcanism at the tip of a propagating arc; the earliest high-Mg andesites in northern New Zealand: Journal of Volcanology and Geothermal Research, v. 195, p. 83-96.

Booden, M.A., Smith, I.M., Mauk, J.L., and Black, P.M., 2012, Geochemical and isotopic development of the Coromandel volcanic zone, northern New Zealand, since $18 \mathrm{Ma}$ : Journal of Volcanology and Geothermal Research, v. 219, p. $22,015-22,032$.
Chen, J., and Huh, C., 1982, Geochemistry of dacites from Chinkuashih area, northeastern Taiwan: Proceedings of the Geological Society of China, no. 25, p. 67-81.

Chiaradia, Massimo, Fontboté, Lluis, and Beate, Bernardo, 2004, Cenozoic continental arc magmatism and associated mineralization in Ecuador: Mineralium Deposita, v. 39, p. 204-222.

Chiaradia, Massimo, Merino, Daniel, and Spikings, Richard, 2009, Rapid transition to long-lived deep crustal magmatic maturation and the formation of giant porphyry-related mineralization (Yanacocha, Peru): Earth and Planetary Science Letters, v. 288, p. 505-515.

Cunningham, C.G., Arribas, Antonio, Jr., Rytuba, J.J., and Arribas, Antonio, Sr., 1989, Evolution of the Los Frailes caldera, Cabo de Gata volcanic field, southeastern Spain: U.S. Geological Survey Open-File Report 89-325, 20 p.

Di Battistini, G.G., Toscani, L.L., Iaccarino, S.S., and Villa, I.M., 1987, K/Ar ages and the geological setting of calcalkaline volcanic rocks from Sierra de Gata, SE Spain: Neues Jahrbuch Fuer Mineralogie, Monatshefte, v. 8, p. 369-383.

Dubé, B., Dunning, G., and Lauzière, K., 1998, Geology of the Hope Brook mine, Newfoundland, Canada-A preserved Late Proterozoic high-sulfidation epithermal gold deposit and its implications for exploration: Economic Geology, v. 93 , p. $405-436$.

du Bray, E.A., John, D.A., Box, S.E., Vikre, P.G., Fleck, R.J., and Cousens, B.L., 2013, Petrographic and geochemical data for Cenozoic volcanic rocks of the Bodie Hills, California and Nevada: U.S. Geological Survey Data Series 764, $10 \mathrm{p}$.

du Bray, E.A., John, D.A., Putirka, Keith, and Cousens, B.L., 2008, Geochemical database for igneous rocks of the ancestral Cascades arc - Southern segment, California and Nevada: U.S. Geological Survey Data Series 439, 1 CD-ROM.

du Bray, E.A., Ludington, S.D., Brooks, W.E., Gamble, B.M., Ratté, J.C., Richter, D.H., and Soria-Escalante, Eduardo, 1995, Compositional characteristics of middle to upper Tertiary volcanic rocks of the Bolivian Altiplano: U.S. Geological Survey Bulletin 2119, 30 p.

Einaudi, M.T., Hedenquist, J.W., and Inan, E.E., 2003, Sulfidation state of fluids in active and extinct hydrothermal systems - Transitions from porphyry to epithermal environments: Society of Economic Geologists Special Publication 10, p. 285-313. 
Fytikas, M., Innocenti, F., Kolios, N., Manetti, P., Mazzuoli, R., Poli, G., Rita, F., and Villari, L., 1986, Volcanology and petrology of volcanic products from the island of Milos and neighbouring islets: Journal of Volcanology and Geothermal Research, v. 28, p. 297-317.

Hedenquist, J.W., Arribas, A., Jr., and Reynolds, T.J., 1998, Evolution of an intrusion-centered hydrothermal systemFar Southeast-Lepanto porphyry and epithermal $\mathrm{Cu}-\mathrm{Au}$ deposits, Philippines: Economic Geology, v. 93, p. 373-405.

Henry, C.D., McDowell, F.W., and Silver, L.T., 2003, Geology and geochronology of granitic batholith complex, Sinaloa, Mexico-Implications for Cordilleran magmatism and tectonics: Geological Society of America Special Paper 374, p. 237-273.

Hollings, P., Cooke, D.R., Waters, P.J., and Cousens, B.L., 2011, Igneous geochemistry of mineralized rocks of the Baguio District, Philippines; implications for tectonic evolution and the genesis of porphyry-style mineralization: Economic Geology, v. 106, p. 1,317-1,333.

Hwang, J., and Meyer, H.A., 1983, Dacite-andesite of the Chinkuashih region, northern Taiwan: Memoir of the Geological Society of China, no. 5, p. 67-84.

Innocenti F., Manetti P., Peccerillo A., and Poli G., 1981, South Aegean volcanic arc-Geochemical variations and geotectonic implications: Bulletin of Volcanology, v. 44, p. 377-391.

Izawa, E., and Cunningham, C.G., 1989, Hydrothermal breccia pipes and gold mineralization in the Washita orebody, Iwato deposit, Kyushu, Japan: Economic Geology, v. 84, p. 715-724.

Izawa, E., and Zeng, N., 2001, Kushikino gold mineralization in a Pliocene volcanic region, Kyushu, Japan: Society of Economic Geologists Guidebook Series, v. 34, p. 53-60.

Izawa, E., Urashima, Y., Ibaraki, K., Suzuki, R., Yokoyama, T., Kawasaki, K., and Taguchi, S., 1990, The Hishikari gold deposit; high-grade epithermal veins in Quaternary volcanoes of southern Kyushu, Japan: Journal of Geochemical Exploration, v. 36, p. 1-56.

Jiang, Si-Hong, Liang, Qing-Ling, Bagas, Leon, Wang, ShaoHuai, Nie, Feng-Jun, and Liu, Yi-Fei, 2013, Geodynamic setting of the Zijinshan porphyry-epithermal $\mathrm{Cu}-\mathrm{Au}-\mathrm{Mo}-\mathrm{Ag}$ ore system, SW Fujian Province, China-Constrains from the geochronology and geochemistry of the igneous rocks: Ore Geology Reviews, v. 53, p. 287-305.

John, D.A., Hofstra, A.H., Fleck, R.J., Brummer, J.E., and Saderholm, E.C., 2003, Geologic setting and genesis of the Mule Canyon low-sulfidation epithermal gold-silver deposit, north-central Nevada: Economic Geology, v. 98, p. 425-463.
Kamenov, B.K., Yanev, Yotzo, Nedialkov, Rossen, Moritz, Robert, Peytcheva, Irena, von Quadt, Albrecht, Stoykov, Stanislav, and Zartova, Aneta, 2007, Petrology of Upper Cretaceous island-arc ore-magmatic centers from central Srednogorie, Bulgaria-Magma evolution and paths: Geochemistry, Mineralogy, and Petrology, v. 45, p. 39-77.

Kay, S., Maksaev, V., Moscoso, R., Mpodozis, C., and Nasi, C., 1987, Probing the evolving Andean lithosphere; mid-late Tertiary magmatism in Chile $\left(29^{\circ}-30^{\circ} 30^{\prime}\right)$ over the modern zone of subhorizontal subduction: Journal of Geophysical Research, v. 92, p. 6,173-6,189.

Konečný, V., Lexa, J., and Hojstričová, V., 1995, The central Slovakia Neogene volcanic field-A review: Acta Vulcanologica, v. 7, p. 63-78.

Leavitt, E.D., and Arehart, G.B., 2005, Alteration, geochemistry, and paragenesis of the Midas epithermal gold-silver deposit, Elko County, Nevada, in Rhoden, H.N., Steininger, R.C., and Vikre, P.G., eds., Geological Society of Nevada Symposium 2005: Window to the World, Reno, Nevada, May 2005, p. 563-627.

Le Maitre, R.W., 2002, Igneous rocks-A classification and glossary of terms ( $2 \mathrm{~d}$ ed.): Cambridge University Press, $236 \mathrm{p}$.

Lipman, P.W., 1975, Evolution of the Platoro caldera complex and related volcanic rocks, southeastern San Juan Mountains, Colorado: U.S. Geological Survey Professional Paper 852, $128 \mathrm{p}$.

Longo, A.A., Dilles, J.H., Grunder, A.L., and Duncan, Robert, 2000, Evolution of calc-alkaline volcanism and associated hydrothermal gold deposits at Yanacocha, Peru: Economic Geology, v. 105, p. 1191-1241.

Losada-Calderon, A.J., McBride, S.L., and Bloom, M.S., 1994, The geology and ${ }^{40} \mathrm{Ar} /{ }^{39} \mathrm{Ar}$ geochronology of magmatic activity and related mineralization in the Nevados del Famatina mining district, La Rioja Province, Argentina: Journal of South American Earth Sciences, v. 7, p. 9-24.

Loucks, R.R., Lemish, J., and Damon, P.E., 1988, Polymetallic epithermal fissure vein mineralization, Topia, Durango, Mexico; Part I, District geology, geochronology, hydrothermal alteration, and vein mineralogy: Economic Geology, v. 83 , p. $1499-1527$.

Maksaev, J.V., Moscoso, D.R., Mpodozis, M.C., and Nasi, P.C., 1984, Las unidades volcanicas y plutonicas del Cenozoico Superior en la Alta Cordillera del Norte Chico $\left(29^{\circ}-31^{\circ} \mathrm{S}\right)$; Geologia, alteracion hidrotermal y mineralizacion: Revista Geologica de Chile, v. 21, p. 11-51. 
Montgomery, A.T., 2012, Metallogenetic controls on Miocene high-sulphidation epithermal gold mineralization, Alto Chicama district, La Libertad, northern Peru: Kingston, Ontario, Canada, Queens University, Ph.D. dissertation, $455 \mathrm{p}$.

Nash, J.T., Fey, D.L., Motooka, J.M., and Siems, D.F., 1990, Geochemical analyses of ore and host rocks, Sleeper goldsilver deposit, Humboldt County, Nevada: U.S. Geological Survey Open-File Report 90-702, 69 p.

Nash, J.T., Utterback, W.C., and Trudel, W.C., 1995, Geology and geochemistry of the Tertiary volcanic host rocks, Sleeper gold-silver deposit, Humboldt County, Nevada: U.S. Geological Survey Bulletin 2090, 63 p.

Nemeth, K.E., 1976, Petrography of the lower volcanic group, Tayoltita-San Dimas district, Durango, Mexico: Austin, University of Texas, M.A. thesis, $141 \mathrm{p}$.

Noble, D.C., and McKee, E.H., 1999, The Miocene metallogenic belt of central and northern Peru: Society of Economic Geologists Special Publication 7, p. 155-193.

Ransome, F.L., Emmons, W.H., and Garrey, G.H., 1910, Geology and ore deposits of the Bullfrog district, Nevada: U.S. Geological Survey Bulletin 407, 130 p.

Ratté, J.C., and Steven, T.A., 1967, Ash flows and related rocks associated with the Creede caldera, San Juan Mountains, Colorado: U.S. Geological Survey Professional Paper 524-H, 58 p.

Redwood, S.D., 1987, The Soledad caldera, Bolivia; a Miocene caldera with associated epithermal $\mathrm{Au}-\mathrm{Ag}-\mathrm{Cu}-\mathrm{Pb}-\mathrm{Zn}$ mineralization: Geological Society of America Bulletin, v. 99 , p. $395-404$.

Roşu, Emilian, Seghedi, Ioan, Downes, Hilary, Alderton, D.H.M., Szakács, Alexandru, Pécskay, Zoltan, Panaiotu, Cristian, Panaiotu, C.E., and Nedelcu, Liviu, 2004, Extension-related Miocene calc-alkaline magmatism in the Apuseni Mountains, Romania-Origin of magmas: Schweizerische Mineralogische und Petrographische Mitteilungen, v. 84, p. 153-172.

Sherlock, R.L., 1993, The geology and geochemistry of the McLaughlin mine sheeted vein complex, northern Coast Ranges, California: Waterloo, Canada, University of Waterloo, Ph.D. dissertation, 309 p.

Simmons, S.F., and Browne, P.R.L., 1990, Mineralogic, alteration and fluid-inclusion studies of epithermal goldbearing veins at the Mt. Muro prospect, Central Kalimantan (Borneo), Indonesia: Journal of Geochemical Exploration, v. 35, p. 63-103.
Simmons, S.F., White, N.C., and John, D.A., 2005, Geological characteristics of epithermal precious and base metal deposits: Economic Geology, 100th Anniversary Volume, p. 455-522.

So, C.S., Zhang, D.Q., Yun, S.T., and Li, D.X., 1998, Alteration-mineralization zoning and fluid inclusions of the highsulfidation epithermal $\mathrm{Cu}-\mathrm{Au}$ mineralization at Zijinshan, Fujian Province, China: Economic Geology, v. 93, p. 961-980.

Staude, John-Mark G., 1995, Epithermal mineralization in the Sierra Madre Occidental, and the metallogeny of northwestern Mexico: Tucson, University of Arizona, Ph.D. dissertation, $248 \mathrm{p}$.

Steven, T.A., and Ratté, J.C., 1960, Geology and ore deposits of the Summitville district, San Juan Mountains, Colorado: U. S. Geological Survey Professional Paper 343, 70 p.

Streckeisen, A., 1976, To each plutonic rock its proper name: Earth-Science Reviews, v. 12, p. 1-33.

Thompson, J.F.H., Abidin, H.Z., Both, R.A., Martosuroyo, S., Rafferty, W.J., and Thompson, A.J.B., 1994, Alteration and epithermal mineralization in the Masuparia volcanic center, central Kalimantan, Indonesian: Journal of Geochemical Exploration, v. 50, p. 429-456.

Thorson, J.P., 1971, Igneous petrology of the Oatman district, Mohave County, Arizona: Santa Barbara, University of California, Ph. D. dissertation, 189 p.

Turner, S., 1997, The Yanacocha epithermal gold deposits, northern Peru-High sulfidation mineralization in a flow dome setting: Golden, Colorado School of Mines, Ph.D. dissertation, $338 \mathrm{p}$.

Van Leeuwen, T.M., Leach, T., Hawke, A.A., and Hawke, M.M., 1990, The Kelian disseminated gold deposit, East Kalimantan, Indonesia, in Hedenquist, J.W., White, N.C., and Siddeley, G., eds., Epithermal gold mineralization of the Circum-Pacific - Geology, geochemistry, origin and exploration, I: Journal of Geochemical Exploration, v. 35, p. $1-61$.

Vikre, P.G., 1985, Precious metal vein systems in the National district, Humboldt County, Nevada: Economic Geology, v. 80, p. $360-393$.

Warren, I., Zuluaga, J.I., Robbins, C.H., Wulftange, W., and Simmons, S.F., 2004, Characterization of epithermal alteration and mineralization at El Peñon, northern Chile: Society of Economic Geologists Special Publication 11, p. 113-139.

Weihed, B.J., Berstrom, U., Billstrom, K., and Weihed, P., 1996, Geology, tectonic setting, and origin of the Paleoproterozoic Boliden $\mathrm{Au}-\mathrm{Cu}$-As deposit, Skellefte district, northern Sweden: Economic Geology, v. 91, p. 1073-1097. 
Wells, R.C., 1937, Analyses of rocks and minerals from the laboratory of the U.S. Geological Survey, 1914-36: U. S. Geological Survey Bulletin 878, 134 p.
Publishing support provided by:

Denver Publishing Service Center

For more information concerning this publication, contact:

Center Director, USGS Central Mineral and Environmental Resources Science Center

Box 25046, Mail Stop 973

Denver, CO 80225

(303) 236-1562

Or visit the Central Mineral and Environmental Resources Science Center Web site at: http://minerals.cr.usgs.gov/ 
Appendix 



\section{Appendix 1. Geochemical and Modal Data for Epithermal Deposits}

[Appendix 1 can be downloaded from http://pubs.usgs.gov/ds875] 


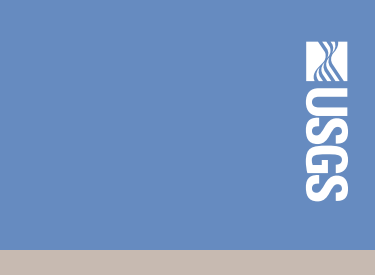

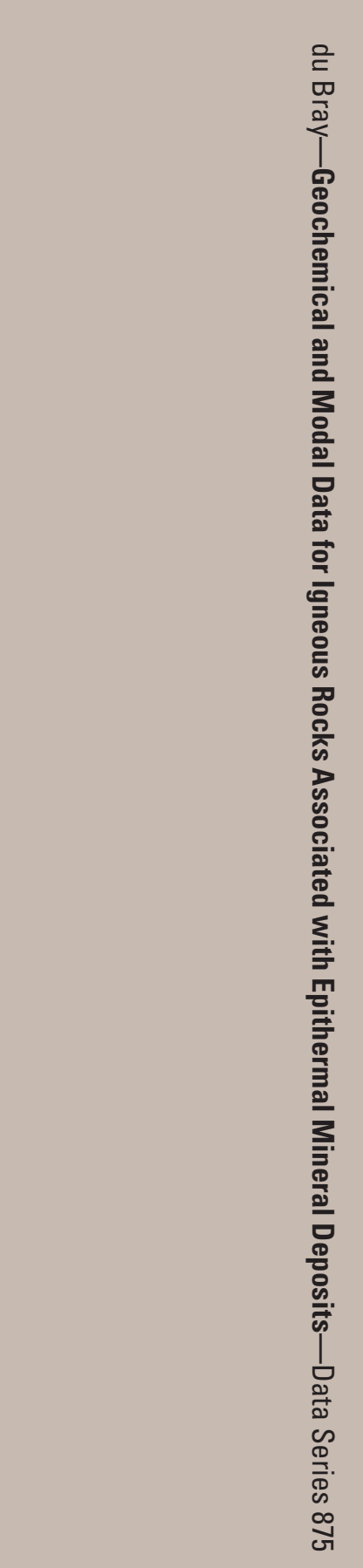

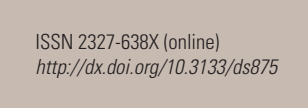

